УДК 343.976

DOI https://doi.org/10.32849/2663-5313/2021.2.40

\title{
Владислав Карелін,
}

докт. юрид. наук,

професор кафедри кримінального, кримінально-виконавчого права та кримінології

Академії Державної пенітениіарної служби

\section{ЗАПОБІГАННЯ КОНТРАБАНДІ НАРКОТИЧНИХ ЗАСОБІВ}

У статті досліджено поняття контрабанди та ї види, питання наркобізнесу та контрабанди наркотичних засобів, психотропних речовин, їх аналогів чи прекурсорів або фальсифікованих лікарських засобів, поширені маршрути, через які здійснюється контрабанда наркотичних засобів, серед яких балканський марирут, північно-чорноморський марирут, східно-середземноморський марирут, циганський маршрут, албанський маршрут, африканський маршрут, угорський маршрут і місиевий маршрут.

Доведено, що натепер ситуачія з контрабандою наркотичних засобів в Україні залишається досить складною, оскільки на неї впливає досить велика кількість чинників, серед них - насамперед збройний конфлікт на сході України, оскільки значна частина украйнсько-російського кордону не контролюється владою Украйни і через нього йде масовий потік наркотичних речовин, який переправляється у країни Західної Європи, деяка частина залишається в Україні, а левова частка залишається в непідконтрольних нашій державі районах Донеиької та Луганської областей; жага легкої наживи на чужому горі представників злочинних угрупувань; недостатня координація правоохоронних органів України з відповідними органами суміжних з нашою краӥною держав щодо обміну інформацією стосовно діяльності злочинних груп, що здійснюють наркотрафік; корумпованість співробітників митнииі та військовослужбовиів прикордонної служби, посадових осіб правоохоронних органів, які забезпечують досудове розслідування кримінальних проваджень щодо контрабанди наркотичних речовин.

Встановлено, що для запобігання контрабанді наркотичних засобів нашій державі слід: ураховувати міжнародний досвід у сфері боротьби з незаконним оборотом наркотичних засобів та психотропних речовин та їх контрабандою у діяльності органів, які їм запобігають, та привести їхню діяльність до міжнародних стандартів; здійснювати підготовку, перепідготовку та підвищення кваліфікаиії прачівників правоохоронних органів, що здійснюють запобігання незаконному обороту наркотичних засобів та їх контрабанді, на базі відповідних відомств зарубіжних країн; перекрити на державному кордоні з Російською Федерачією, Білоруссю, Молдовою, Польщею, Словаччиною, Угорщиною, Румунією канали надходження в Украйну наркотичних засобів; викрити і ліквідувати канали контрабандного надходження в Україну наркотичних засобів; вивчити досвід підрозділів боротьби з наркобізнесом і трансначіональною наркозлочинністю у зарубіжних країнах з метою його запровадження.

Ключові слова: злочин, контрабанда, наркотичні засоби, наркозлочинність, наркобізнес, наркотрафік, транснаціональна наркозлочинність.

Постановка проблеми. Формування сильної та водночас цивілізованої правової держави завжди потребуватиме розв'язання великої кількості проблем, пов'язаних із запобіганням окремим видам злочинів. Звісно ж, не є винятком і такий напрям, як належна організація запобігання контрабанді наркотичних засобів, що, до речі, зумовлюється процесами, котрі відбуваються як в Україні, так і у світі. Вона здійснюється організованими злочинними групами, які використовують нашу державу як транзитний коридор до країн Західної Свропи, хоча досить велика кількість наркотиків також залишається і у нас. За оцінками
ООН, число осіб, що вживають наркотики, натепер становить не менше 185 млн. чоловік (тобто 3 \% всього населення планети, або близько 12 \% населення у віці від 15 до 30 років). Що стосується нашої держави, то, за статистикою МВС України, станом на 01.06. 2020 року кількість наркозалежних, що офіційно перебували на обліку, перевищила 150 тисяч. В області загальна кількість хворих становить 1090 осіб, серед них 372 це молодь до 35 років. У групі ризику знаходиться 1562 особи, з них 1267 - молодь до 35 років та 11 дітей віком до 18 років. Однак, на думку фахівців, у нашій державі їх понад мільйон [1]. 
Тому сьогодні є нагальна потреба у перегляді процесів виявлення, розслідування даних злочинів та запобігання їм. Із вищезазначеного випливає, що запобігання контрабанді наркотичних речовин забезпечуе дотримання прав і свобод громадян України, їне фізичне та психічне здоров'я і таким чином порядок у самій державі.

Аналіз останніх досліджень і публікацій. Теоретико-правовою основою дослідження особливостей контрабанди наркотичних засобів та шляхів запобігання їй стали праці Л.В. Багрій-Шахматова, О.Ф. Бантишева, Ю.В. Бауліна, В.Д. Басай, О.І. Бойка, В.М. Володька, Н.О. Гуторової, О.М. Джужи, А.І. Долгової А.П. Закалюка, О.В. Козаченко, О.О. Кравченко, О.М. Литвинова, М.І. Мельника, Н.А. Мирошниченко, А.А. Музики, О.В. Наден, А.М. Полях, Ю.Г. Пономаренка, В.В. Сташиса, Є.Л. Стрєльцова, М.С. Таганцева, В.Я. Тація, М.І. Хавронюка, B.I. Шакуна, В.М. Шевчука, В.А. Щербань, O.М. Ясінської та ін.

Мета статті полягає в дослідженні особливостей такого виду злочину, як контрабанда наркотичних засобів, способів та шляхів їх проникнення на територію України, а також здійснення запобігання таким злочинам в Україні.

Виклад основного матеріалу. У Великому тлумачному словнику сучасної української мови контрабанду визначають як незаконне, таємне перевезення або перенесення через державний кордон товарів, коштовностей, заборонених або обкладених митом [2, с. 450].

Деякі вчені під контрабандою розуміють переміщення товарів, валюти, цінностей (зокрема, культурно-історичних), отруйних, сильнодіючих, радіоактивних, вибухових речовин та ін. предметів через митний кордон країни поза митним контролем або з приховуванням від митного контролю, вчинене окремою особою або групою осіб, які організувалися для заняття контрабандою [3, с. 128].

Але вітчизняний законодавець дав інше визначення, поділивши поняття контрабанди на декілька різновидів:

1) економічна (загальнокримінальна) контрабанда, тобто, як сказано у ст. 201 Кримінального кодексу України (далі - КК У країни), контрабанда - це переміщення через митний кордон України поза митним контролем або з приховуванням від митного контролю культурних цінностей, отруйних, сильнодіючих, вибухових речовин, радіоактивних матеріалів, зброї або боєприпасів, частин вогнепальної нарізної зброї, а також спеціальних технічних засобів негласного отримання інформації [4];

2) спеціальна контрабанда, яка передбачена ст. 305 КК України і включає в себе контрабанду наркотичних засобів, психотропних речовин, їх аналогів чи прекурсорів або фальсифікованих лікарських засобів, тобто їх переміщення через митний кордон України поза митним контролем або з приховуванням від митного контролю [4].

Що ж стосується визначення наркотичних засобів, то їх слід визначати за трьома критеріями:

1) за медичним критерієм - це природні чи синтетичні речовини, які мають специфічний вплив на центральну нервову систему людини (ейфорія, галюцинація, ступор, нечутливість до болю);

2) за соціальним критерієм - немедичне вживання наркотичних засобів набуло ознак соціального явища, яке негативно впливає на соціальні зв'язки в суспільстві.

3) юридичний критерій поєднує медичний та соціальний критерії і передбачає визнання певних засобів забороненими в законодавстві та включення іх у відповідний нормативно-правовий акт. Натепер таким актом є Перелік наркотичних засобів, психотропних речовин і прекурсорів, затверджений постановою Кабінету Міністрів України [5].

Контрабанда наркотичних засобів є складовою частиною наркобізнесу, своє чергою, як зазначає Г.М. Бірюков, наркобізнес - це специфічний злочинний промисел, система заборонених нормами національного і міжнародного права діянь: виробництво або закупівля наркотичних засобів, психотропних речовин та прекурсорів; доставка їх до місця реалізації; збут, продаж їх споживачам [6, с. 17].

Транснаціональний наркобізнес - окремий вид організованої транснаціональної злочинності, який характеризується структурованою системою високоорганізованих і ретельно законспірованих злочинних угруповань, які займаються міжрегіональною, у ряді випадків - міжнародною, злочинною діяльністю у вигляді промислу, предметом якого є наркотичні засоби, з метою систематичного отримання максимальних прибутків та надприбутків, використовуючи у своїх інтересах як державні структури, так і інститути громадянського суспільства [7, с. 13].

Транснаціональному наркобізнесу більше, ніж іншим напрямам організованої злочинної діяльності, властиві такі ознаки:

a) ієрархічна i багатоструменева структура кримінальних формувань, що передбачає чітке підпорядкування груповій дисципліні та вказівкам організатора; 

нання

б) організаційна стабільність наркооб'єд-

в) завчасна підготовка, планування і кваліфіковане вчинення злочинів;

г) функціональна диференціація членів злочинного об'єднання (розподіл ролей між ними, у тому числі й під час вибору і вербування співучасників);

д) наявність ретельно замаскованих зв’язків, що базуються на чіткій самоорганізації, високому рівні конспірації;

є) продумана підготовка засобів реалізації і збуту наркотиків;

ж)стійка спрямованість на створення корумпованих зв'язків у правоохоронних органах;

3) чітка система дій, пов'язаних 3 незаконними операціями 3 наркотиками;

i) монополізація прагнень до поставлених цілей;

к) гостра конкурентна боротьба і суперництво, що поряд зі злочинними контактами і взаємодією існують між окремими формуваннями наркомафії, які нерідко набувають форм озброєного протистояння та фізичного знищення на грунті розподілу і перерозподілу ринків збуту. Запекла міжусобна боротьба призводить до виникнення найпотужніших синдикатів [7, с. 13-14]

Слід зазначити, що $€$ вісім основних маршрутів, через які здійснюється контрабанда наркотичних засобів, серед них:

1. Балканський маршрут: починається у Південно-Західній Азії, проходить через території Ірану та Туреччини, а потім поділяється на дві гілки, які пролягають через Балкани. Перша з них, яку називають «Північна дорога», пролягає через Болгарію-Румунію-У горщину-Австрію-Німеччину. Друга гілка - «Південна дорога» - морем через Туреччину та Грецію має вихід до Італії [8];

2. Північно-Чорноморський маршрут також має два відгалуження, й обидва вони починаються в Афганістані. Перший маршрут далі пролягає територією країн Центральної Азії до ринків Західної Європи через Російську Федерацію (далі - РФ), Україну, Білорусь та Республіку Польща. Другий маршрут з Афганістану проходить через Іран, Азербайджан, Вірменію, Грузію, Росію, звідки пролягає до країн Західної Свропи [8];

3. Східно-Середземноморський маршрут: розпочинається в портах Пакистану та пролягає до ринків Західної Європи через Індійський океан, Червоне море, Суецький канал, південну частину острова Кіпр [8];

4. Циганський маршрут: а) наркотики виробляються кустарним способом в Україні (у місцях компактного проживання гро- мадян України циганської національності), направляються автомобільним транспортом для продажу в Білорусі та РФ (напрямки: м. Житомир-Гомель (Білорусь), м. ЛуганськРостов-на-Дону, Шахтинськ (РФ)) через пункт пропуску на україно-білоруському державному кордоні «Виступовичі-авто», на україно-російському державному кордоні «Ізварине», «Довжанський» [8];

5. Албанський маршрут: починається (виробництво наркотиків) у регіонах із компактним проживанням албанської діаспори в країнах Балканського півострова (Албанія, Македонія, Боснія і Герцеговина), далі через Румунію, Угорщину наркотики переміщуються автомобільним транспортом в Україну через п/п на україно-румунському кордоні «Дякове», «Порубне», на україноугорському кордоні - «Вилок», «Лужанка», «Косине», «Дзвінкове», де після їх розподілу в албанських діаспорах у регіонах України морським або повітряним транспортом доставляються наркокур'єрами до Туреччини або залізничним - до РФ [8];

6. Африканський маршрут: починається (виробництво наркотиків) у країнах Центральної та Північно-Західної Африки, транзитом через європейські країни, далі повітряним або автомобільним транспортом наркотики потрапляють в Україну. Основні п/п, через які здійснюється ввезення в Україну: автомобільні - «Тиса», «Ужгород», «Краківець», «Ягодин», повітряні - «Львів», «Одеса», «Дніпро», «Запоріжжя» [8];

7. Угорський маршрут: в Україну потрапляють i наркотики, які були вироблені в Угорщині. Іхх переправляють залізничним або автомобільним транспортом для продажу в Україні, в регіони компактного проживання громадян України, угорців за національністю, через п/п на україно-угорському кордоні: «Чоп (Дружба)», «Чоп (Тиса)», «Дзвінкове», «Лужанка», «Вилок» [7];

8. Місцевий кримінальний маршрут: найбільш розвинений вид злочинної діяльності (пов'язаний з наркобізнесом) - через державний кордон на Північному Сході та Півдні України. Перевезення здійснюють дрібні наркокур'єри через автомобільні та залізничні пункти пропуску на україноросійському та україно-молдовських кордонах [8].

Що стосується нашої держави, то протягом 2020 року прикордонники спільно із взаємодіючими органами виявили 606 кілограмів наркотиків. 3 них - майже 460 кг кокаїну, близько 80 кг марихуани, понад 30 кг конопель, близько 26 кг наркотичних лікарських засобів та інші речовини рослинного й синтетичного походження. 
Зазначається, що найрезультативнішим стало перекриття потоків на морському напрямку: в портах вилучено близько 450 кг кокаїну.

Майже 60 кілограмів наркотиків виявили на кордоні з Росією (у 2019 р. - 22 кг). Із них близько 50 кг - марихуана та понад 9 кг кокаїн. [9].

Основними способами контрабандного переміщення наркотичних засобів через державний кордон України як на транзитних каналах, так і на місцевих є: використання спеціально обладнаних схованок у транспортних засобах (тягачах), вантажах в особистих речах, передачах; в обладнаних схованках в інших товарах, які дозволені до вільного переміщення через кордон (у металевих упаковках продуктів харчування; деревині, дерев’яних брусах; в інших пакувальних матеріалах товарів продовольчої та промислової груп); у конструктивних особливостях транспортних засобів; поза пунктами пропуску через державний кордон. Для наркотрафіку гашишу, найчастіше використовується: обладнання схованок у транспортних засобах (вантажних автомобілях та мікроавтобусах) на спеціалізованих станціях технічного обслуговування автомобілів (обладнання подвійного дна, подвійних стінок автомобілів та причепів; тайників у бензобаках, запасних колесах, тощо) [10, c. 10-11].

\section{Висновки}

Сьогодні ситуація з контрабандою наркотичних засобів в Україні залишається досить складною, оскільки на неї впливае досить велика кількість чинників, серед них - насамперед збройний конфлікт на сході України, оскільки значна частина українсько-російського кордону не контролюється владою України і через нього йде масовий потік наркотичних речовин, який переправляється у країни Західної Європи, деяка частина залишається в Україні, а левова частка залишається в непідконтрольних нашій державі районах Донецької та Луганської областей; по-друге, жага легкої наживи на чужому горі представників злочинних угрупувань; по-третє, недостатня координація правоохоронних органів України 3 відповідними органами суміжних 3 нашою країною держав щодо обміну інформацією стосовно діяльності злочинних груп, що здійснюють наркотрафік; по-четверте, корумпованість співробітників митниці та військовослужбовців прикордонної служби, посадових осіб правоохоронних органів, які забезпечують досудове розслідування кримінальних про- ваджень щодо контрабанди наркотичних речовин.

Що стосується запобігання контрабанді наркотичних засобів, то нашій державі слід: ураховувати міжнародний досвід у сфері боротьби 3 незаконним оборотом наркотичних засобів та психотропних речовин та їх контрабандою у діяльності органів, які ім запобігають, та привести їхню діяльність до міжнародних стандартів; здійснювати підготовку, перепідготовку та підвищення кваліфікації працівників правоохоронних органів, що здійснюють запобігання незаконному обороту наркотичних засобів та їх контрабанді, на базі відповідних відомств зарубіжних країн; перекрити на державному кордоні 3 Російською Федерацією, Білоруссю, Молдовою, Польщею, Словаччиною, Угорщиною, Румунією канали надходження в Україну наркотичних засобів; викривати і ліквідовувати канали контрабандного надходження в Україну наркотичних засобів; вивчити досвід підрозділів боротьби з наркобізнесом і транснаціональною наркозлочинністю у зарубіжних країнах з метою його запровадження.

\section{Список використаних джерел:}

1. Право знати: Кримінальна відповідальність за розповсюдження наркотиків. URL: https://www.legalaid.gov.ua/multymedia/ kryminalna-vidpovidalnist-za-rozpovsyudzhennyanarkotykiv/ (дата звернення: 25.01.2021).

2. Великий тлумачний словник сучасної української мови / уклад і голов. ред. В.Т. Бусел. Київ: ВТФ «Перун», 2004. 1440 с.

3. Гіжевський В.К., Головченко В.В., Ковальський В.С. Популярна юридична енциклопедія. Київ: Юрінком Інтер, 2002. 528c.

4. Кримінальний кодекс України : Закон України від 05.04.2001 № 2341-III. Відомості Верховної Ради України. 2001. № 25-26. Ст. 131. URL: https://protocol.ua/ua/kriminalniy kodeks ukraini_stattya_305/(дата звернення: 25.01.2021).

5. Наркота і закон: поняття, класифікація, види наркотичних засобів, психотропних речовин і прекурсорів. URL: https://protocol.ua/ua/ narkota i zakon ponyattya klasifikatsiya vidi narkotichnih_zasobiv_psihotropnih_rechovin_i_prekursoriv/ (дата звернення: 26.01.2021).

6. Бірюков Г.М. Стратегічні й тактичні основи протидії наркобізнесу в Україні. Міжнародне співробітничтво у сфері протидї незаконному обігу наркотичних засобів $i$ психотропних речовин : матер. міжнар. наук.-практ. конф. Дніпропетровськ: ДДУВС. 2007. С. 16-21

7. Левченко Ю.О. Фондова лекція з навчального курсу «Незаконний обіг наркотичних засобів та його профілактика». Київ: НАВС, 2015. 58c.

8. Практика розгляду судами справ про злочини у сфері обігу наркотичних засобів, психотропних речовин, їх аналогів або прекурсорів. 
URL: https://zakon.rada.gov.ua/laws/show/v0011 700-08\#Tехt (дата звернення: 26.01.2021).

9. Прикордонники цьогоріч виявили понад 600 кілограмів наркотиків. URL: https://www. ukrinform.ua/rubric-society/3156140-prikordonnikicogoric-viavili-ponad-600-kilogramiv-narkotikiv. html (дата звернення: 26.01.2021).
10. Ніколаєнко Т., Шаталюк Б. Контрабанда наркотичних засобів як глобальна міжнародна загроза. Вісник Національної академії Державноі прикордонної служби України. Серія «Юридичні науки». 2019. Вип. № 4. С. 1-17. URL: 322-Текст статті-936-1-10-20200522.pdf. (дата звернення: 26.01.2021).

\section{Vladyslav Karelin. Prevention of drug smuggling}

The concept of smuggling and its types, drug trafficking and smuggling of narcotic drugs, psychotropic substances, their analogues or precursors or counterfeit drugs, common routes through which drug smuggling is carried out, including the Balkan route, North Black Sea route, Eastern Mediterranean route, Gypsy route, Albanian route, African route, Hungarian route and local route.

It is proved that today the situation with drug smuggling in Ukraine remains quite complicated, as it is influenced by a large number of factors, primarily the armed conflict in eastern Ukraine, as much of the Ukrainian-Russian border is not controlled by the Ukrainian authorities and massive flow of drugs, which is transported to Western Europe, some remain in Ukraine and the lion's share remains in areas not controlled by our state, Donetsk and Luhansk regions; thirst for easy profit on someone else's grief by representatives of criminal groups; insufficient coordination of law enforcement agencies of Ukraine with the relevant authorities of neighboring countries with the exchange of information on the activities of criminal groups engaged in drug trafficking; corruption of customs officers and border guards, law enforcement officials who provide pre-trial investigation of criminal proceedings on drug smuggling.

It is established that in preventing drug smuggling, our state should: take into account international experience in combating illicit trafficking in narcotic drugs and psychotropic substances and their smuggling in the activities of bodies that prevent them and bring their activities to international standards; training, retraining and advanced training of law enforcement officers involved in the prevention of drug trafficking and smuggling on the basis of relevant departments of foreign countries; blocking the state border with the Russian Federation, Belarus, Moldova, Poland, Slovakia, Hungary, Romania and drug supply channels to Ukraine; detection and elimination of channels of smuggling of drugs into Ukraine; study of the experience of units in the fight against drug trafficking and transnational drug crime in foreign countries in order to implement their experience.

Key words: crime, smuggling, drugs, drug crime, drug business, drug trafficking, transnational drug crime. 